\title{
PENERAPAN PENDEKATAN BEHAVIORAL OPERANT CONDITIONING PADA PEMBELAJARAN PAI DI SMA NEGERI 3 GOWA
}

\author{
Agustina Rahayu, Wahyuni Ismail, Saprin \\ Fakultas Tarbiyah dan Keguruan \\ Universitas Islam Negeri Alauddin Makassar \\ Email: agustinarahayu80@yahoo.co.id,wismail.shivdasany@gmail.com
}

\begin{abstract}
This study aims to find out the application of behavioral operant conditioning approach in learning Islamic education in state high school 3 Gowa, knowing the supporting factors and inhibiting the application of behavioral operant conditioning approach in Islamic education learning in state high school 3 Gowa and to know the result of applying behavioral operant conditioning approach on Islamic education learning in state high school 3 Gowa. The type of research used is descriptive qualitative research. This thesis uses primary and secondary data sources. Methods of data collection are observation, interview and documentation. Data analysis is data reduction, display data (presentation of data) and conclusion. The results showed that the implementation of behavioral operant conditioning approach on learning Islamic education in state high school 3 Gowa has been running well because Islamic education teachers have made lesson plans, implement learning according to lesson plan and evaluate to students on each sub-subject matter that can not be separated from provision of positive and negative reinforcement, although sometimes in the implementation of learning is less in accordance with the lesson plan that has been made by teachers Islamic education. In addition, after applying the behavioral operant conditioning approach to Islamic education learning in state high school 3 Gowa teachers also gained advantages and disadvantages of behavioral operant conditioning approach. The advantages obtained are students more enthusiastic and competing in following the learning process, can change student behavior to be better and motivated students in order to learn more enterprising. While the lack of a student who feels envy to students who excel and student behavior more wins.
\end{abstract}

Keywords: Behavioral Operant Conditioning, Learning Islamic Education

\section{PENDAHULUAN}

\section{A. Latar Belakang}

$\mathrm{P}$ endidikan nasional secara garis besar memiliki tujuan yaitu sebagai upaya membentuk anak didik yang memiliki kompetensi sains-teknologi maupun sainsagama, atau agar mereka berilmu pengetahuan tekhnologi, beriman dan bertaqwa. Dapat pula dikatakan bahwa tujuan pendidikan nasional adalah menciptakan manusia 
Indonesia yang memiliki pengetahuan, berakhlak mulia, berkepribadian, dan berkarakter. $^{1}$

Agar tujuan pendidikan dapat tercapai yang ditandai dengan keberhasilan peserta didik dalam belajar sangat ditentukan oleh strategi atau pendekatan pembelajaran yang dilakukan oleh guru. ${ }^{2}$ Salah satu pendekatan yang biasa dilakukan oleh guru adalah pendekatan behavioral operant conditioning yang ditemukan oleh Burrhusm Frederic Skinner. Pendekatan behavioral operant conditioning adalah sebuah teori belajar yang lebih menekankan pada perubahan perilaku-perilaku. Teori ini bertujuan untuk menghilangkan perilaku yang tidak diharapkan dan meningkatkan perilaku yang diharapkan. Hal ini dapat terjadi apabila ada dua pengaruh yang mendahuluinya dan pengaruh yang mengikutinya.

Menurut Anwar, "Sistem pembentukan perilaku yang ditawarkan oleh Skinner didasarkan pada cara kerja yang menentukan (operant conditioning). Ia berpendapat bahwa perilaku yang diikuti oleh stimulus-stimulus pengunggah (penguat) cenderung akan dilakukan kembali pada masa-masa selanjutnya dan perilaku yang tidak lagi diikuti oleh stimulus-stimulus penguat cenderung memperkecil kemungkinan untuk dilakukan lagi pada masa-masa mendatang". 3

Berdasarkan hasil observasi yang sudah dilakukan di SMAN 3 Gowa, pada dasarnya guru PAI telah menerapkan pendekatan behavioral operant conditioning yang ditandai dengan guru PAI memberikan penguatan kepada siswa, baik penguatan positif maupun penguatan negatif. Akan tetapi, masih ada siswa yang yang terkadang membangkan atau memiliki kepribadian yang kurang baik kepada guru khususnya guru Pendidikan Agama Islam. Sehingga, apabila hal ini tidak ditanggulangi, maka akan membuat kepribadian siswa semakin memburuk. Selain itu, ada pula siswa yang minat belajarnya turun. Hal ini ditandai dengan keraguan siswa dalam bertanya maupun mengeluarkan pendapat. Sehingga apabila hal ini tidak ditanggulangi maka akan membuat minat belajar siswa semakin menurun.

Berdasarkan latar belakang di atas, maka peneliti berminat untuk melakukan penelitian tentang penerapan pendekatan behavioral operant conditioning. Peneliti ingin menganalisis faktor pendukung dan penghambat penerapan pendekatan behavioral operant conditioning di suatu sekolah, terkhusus di SMA Negeri 3 Gowa.

${ }^{1}$ Jalaluddin dan Abdullah Idi, Filsafat Pendidikan: Manusia, Filsafat dan Pendidikan, Jakarta: PT Rajagrafindo Persada, 2013, h. 205.

${ }^{2}$ Dadang Suhardan, dkk, Manajemen Pendidikan, Bandung: Alfabeta, 2014, h. 103.

${ }^{3}$ Chairil Anwar, Teori-Teori Pendidikan: Klasik Hingga Kontemporer, Yogyakarta: IRCiSoD 2017, h. $48-49$. 


\section{B. Tinjauan Pustaka}

\section{Behavioral Operant Conditioning}

Menurut Khodijah, "Ada banyak teori belajar termasuk paradigma behavioristik, salah satunya ialah teori Operant Conditioning oleh Burrhusm Frederic Skinner. Dinamakan operant conditioning karena respons bereaksi terhadap lingkungan sebagai efek yang ditimbulkan oleh reinforcer. Menurut Skinner, sebagian besar perilaku manusia adalah berupa respons atau jenis perilaku operant. Kemungkinan dimodifikasi perilaku tersebut juga boleh dikatakan tak terbatas. Fokus penelitian ini adalah bagaimana menimbulkan, mengembangkan, dan memodifikasi perilaku operant tersebut dengan penguatan (reinforcement)". ${ }^{4}$

Teori behavioral operant conditioning memiliki prinsip-prinsip. Berikut prinsipprinsip operant conditioning:

\section{Reinforcement}

Reinforcement merupakan suatu proses yang memperkuat perilaku atau memperbesar kesempatan agar perilaku tersebut dapat terjadi lagi. Reinforcement terdiri dari dua kategori yaitu positif dan negatif. ${ }^{5}$

Menurut Skinner, perilaku terbentuk oleh konsekuensi yang ditimbulkannya. Konsekuensi yang menyenangkan (positive reinforcement/ penguatan positif) atau (reward/hadiah) akan membuat perilaku yang sama akan diulangi lagi, sebaliknya konsekuensi yang tidak menyenangkan (negative reinforcement/penguatan negatif) atau (punishment/hukuman) akan membuat perilaku dihindari atau memperkecil kemungkinan perilaku dilakukan lagi pada masa-masa mendatang. ${ }^{6}$

\section{Punishment}

Punishment berperan untuk memperlemah atau mengurangi perilaku yang bisa terjadi pada masa mendatang. Hukuman seharusnya tidak diterapkan keculi apabila dalam kondisi yang mendesak atau terpaksa. Seelain itu, pmberian hukuman bisa diterapkan dengan catatan bahwa hukuman tersebut harus pada garis wajar dan tidak terlalu kejam. ${ }^{7}$

\section{Shaping}

Shaping (pembentukan respons) merupakan suatu teknik yang dilakukan dengan cara menguatkan perilaku individu pada setiap kali ia bertindak kearah yang diinginkan, sehingga ia dapat menguasai atau belajar merespons sampai tidak perlu lagi menguatkan respons tersebut.

\section{Extinction}

Extinction (eliminasi kondisi) merupakan perlakuan dengan menghilangkan

\footnotetext{
${ }^{4}$ Nyayu Khodijah, Psikologi Pendidikan, Jakarta: PT RajaGrafindo Persada, 2016, h. 69.

${ }^{5}$ Nyayu Khodijah, Psikologi Pendidikan, Jakarta: PT RajaGrafindo Persada, 2016, h. 69.

${ }^{6}$ Nyayu Khodijah, Psikologi Pendidikan, h. 69-70.

7 Thahroni Taher, Psikologi Pembelajaran Pendidikan Agama Islam, PT RajaGrafindo Persada: Jakarta, 2013, h. 46.
} 
penguatan dari perilaku yang dipelajari dengan menghentikan penguat dari perilaku tersebut. Contohnya, seorang Ibu sering memberikan penguatan negatif terhadap sikap pemarah anaknya dengan memberinya perhatian. Jika Ibu tersebut mengabaikan kemarahan anaknya dengan memberinya perhatian khusus, frekuensi kemarahan dari anak tersebut seharusnya akan berkurang. Namun, sang anak akan mengulangi kemarahannya bila tidak mendapat perhatian.

\section{Generalization dan Discrimination}

Generalisasi merupakan penyamarataan perilaku atau respons dari stimulus yang sama untuk diaplikasikan dalam bentuk yang lain. Dengan kata lain, individu cenderung melakukan generalisasi terhadap sesuatu yang dipelajarinya. Contohnya, anak yang memperoleh penguatan kasih sayang dari orang tuanya lantaran meminang dan menyayangi anjing keluarganya, maka ia akan segera melakukan respons meminang anjing tersebut dengan anjing yang lain. Biarpun demikian, generalisasi dapat dikendalikan dengan latihan diskriminasi. Diskriminasi merupakan respons individu terhadap suatu penguatan, tetapi tidak terhadap jenis penguatan yang lain. Latihan diskriminasi ini akan efektif jika terdapat stimulus diskriminatif yang jelas dalam membedakan kasus. Lalu, respons harus dilakukan secara khusus dan mesti memperoleh penekanan. Dalam generalisasi, sebuah perilaku yang telah dipelajari pada situasi tertentu akan digunakan lagi pada kesempatan yang lain, namun situasinya sama. Contohnya, Toni yang diberi penguatan dengan tertawa atas ceritanya yang lucu, di suatu tempat ia akan mengulangi ceritanya yang sama di restoran, pesta, atau resepsi pernikahan.

Diskriminasi adalah suatu proses belajar bahwa suatu perilaku akan diperkuat dalam suatu situasi, namun tidak dalam situasi lain. Seseorang akan belajar bahwa menceritakan leluconnya di temapat ibadah atau dalam situasi bisnis yang memerlukan keseriusan, niscaya tidak akan menyebabkan orang tertawa. Maka orang tersebut akan belajar menceritakan leluconnya hanya ketika ia berada pada situasi yang riuh dan banyak orang. ${ }^{8}$

\section{Pembelajaran Pendidikan Agama Islam}

Pembelajaran diartikan sebagai suatu pengaruh permanen atas perilaku, pengetahuan, dan keterampilan berpikir yang diperoleh melalui pengalaman. ${ }^{9}$ Selain itu, dapat pula dipahami bahwa pembelajaran adalah suatu sistem yang terdiri dari sejumlah komponen yang terorganisasi antara lain tujuan pembelajaran, materi pembelajaran, strategi, metode, media/alat peraga, pengorganisasian kelas, evaluasi pembelajaran dan tindak lanjut pembelajaran (remedia pengayaan). Pembelajaran dapat pula diartikan sebagai suatu proses, sehingga pembelajaran merupakan rangkaian upaya atau kegiatan guru dalam rangka membuat akhlak peserta didik menjadi baik. ${ }^{10}$ Berdasarkan penjelasan

\footnotetext{
${ }^{8}$ Chairil Anwar, Teori-Teori Pendidikan: Klasik Hingga Kontemporer, h. 54-56.

${ }^{9}$ John W. Santrock, Psikologi Pendidikan, Jakarta: Prenadamedia Group, 2015,h. 266.

10 Nurkhalisah Latuconsina, Pengelolaan dalam Kelas Pembelajaran, Makassar: Alauddin University Press, 2013, h. 7.
} 
di atas, maka dapat disimpulkan bahwa pembelajaran ialah suatu perilaku yang permanen, pengetahuan dan keterampilan yang didapatkan melalui proses.

Menurut Majid, "Pendidikan Agama Islam merupakan upaya sadar dan terencana dalam rangka menyiapkan peserta didik agar dapat mengenal, memahami, menghayati, mengimani, dan berakhlak mulia dalam menjalankan ajaran agama Islam, dari sumber utamanya yaitu Al-Quran dan Al-Hadis, melalui kegiatan bimbingan, pengajaran, latihan, serta penggunaan pengalaman yang disertai dengan tuntutan untuk menghormati penganut agama lain dalam hubungannya dengan kerukunan antarumat beragama dalam masyarakat hingga terwujud kesatuan dan persatuan bangsa". ${ }^{11}$

Menurut Tayar Yusuf Pendidikan Agama Islam merupakan usaha sadar seseorang yang lebih tua atau generasi tua dimana ia lebih mengetahui atau berpengalaman untuk mengalihkan pengelaman, pengetahuan, kecakapan, dan keterampilan kepada seseorang yang lebih muda atau generasi muda agar generasi muda kelak menjadi manusia muslim, bertakwa kepada Allah swt. berbudi pekerti luhur, berkepribadian yang memahami, menghayati, dan mengamalkan ajaran agama Islam dalam kehidapannya. ${ }^{12}$ Pendidikan Islam memiliki fungsi sebagai berikut:

1) Sebagai pengembangan, yaitu untuk meningkatkan keimanan dan ketakwaan siswa kepada Allah swt. yang telah ditanamkan di lingkungan keluarganya. Pada dasarnya orang tua merupakan orang pertama yang berkewajiban untuk menanamkan keimanan dan ketakwaan kepada siswa. Sehingga sekolah berfungsi untuk menumbuh kembangkan lebih lanjut diri siswa melalui bimbingan, pengajaran, dan pelatihan agar keimanan dan ketakwaan siswa dapat berkembang secara optimal sesuai dengan tingkat perkembangannya.

2) Penanaman nilai yang berfungsi sebagai pedoman hidup untuk mencari kebahagiaan di dunia dan diakhirat.

3) Penyesuaian mental, yaitu menyesuaiakan diri dengan lingkungannya baik lingkungan fisik maupun lingkungan sosial dan dapat merubah lingkungannya sesuai dengan ajaran agama Islam.

4) Perbaikan, yaitu untuk memperbaiki kesalahan, kekurangan, dan kelemahankelemahan siswa dalam aspek keyakinan, pemahaman, dan pengalaman ajaran dalam kehidupan sehari-hari.

5) Pencegahan, yaitu berfunggsi untuk menangkal hal-hal negatif yang ada di lingkungan atau budayanya yang dapat membahayakan dan menghambat perkembangannya menuju manusia Indonesia seutuhnya.

6) Pengajaran tentang ilmu pengetahuan keagamaan secara umum seperti alam, nyata dan nirnyata, sistem dan fungsionalnnya.

11 Abdul Majid, Belajar dan Pembelajaran Pendidikan Agama Islam, Bandung: PT Remaja Rosdakarya, 2014, h. 11-12.

${ }^{12}$ Abdul Majid, Belajar dan Pembelajaran Pendidikan Agama Islam, h. 12. 
7) Penyaluran, yaitu berfungsi untuk menyalurkan anak-anak yang memiliki bakat khusus dalam bidang keagamaan sehingga bakat tersebut dapat berkembang secara optimal dan pada akhirnya dapat dimanfaatkan bagi dirinya sendiri dan orang lain. ${ }^{13}$

\section{METODE PENELITIAN}

Jenis penelitian ini adalah penelitian deskriptif kualitatif yaitu mendeskripsikan suatu peristiwa atau objek yang menjadi fokus penelitian. Metode penelitian kualitatif adalah suatu metode penelitian yang berlandaskan pada postpositivisme, filsafat dan digunakan untuk meneliti pada kondisi obyek yang alamiah, sehingga peneliti merupakan instrument kunci didalam penelitiannya sendiri. ${ }^{14}$ Pendekatan yang dipergunakan oleh peneliti ialah pendekatan kualitatif. Pendekatan kualitatif adalah suatu penelitian yang bertujuan untuk mendeskripsikan atau menggambarkan suatu peristiwa, perilaku orang atau suatu keadaan diwilayah tertentu secara rinci dan mendalam dalam bentuk narasi. ${ }^{15}$

Sumber data yang digunakan oleh peneliti ialah data primer dan sekunder. Data primer merupakan data yang diperoleh langsung dari lapangan atau tempat penelitian yang ingin diteliti. Sedangkan sumber utama dalam penelitian kualitatif ialah tindakan, perilaku dan kata-kata yang didapatkan dari sumber penelitian. Peneliti mewawancarai langsung guru dan peserta didik di SMA Negeri 3 Gowa. Peneliti wawancarai guru pendidikan Agama dan budi pekerti berjumlah 2 orang sedangkan siswa yang diwawancarai berjumlah 6 orang. Sedangkan data sekunder yaitu data yang didapatkan dari sumber bacaan dan sumber lainnya yang terdiri dari surat catatan serta dokumen resmi dari sekolah. Peneliti menggunakan data sekunder agar penemuan dan informasi yang telah dikumpulkan dapat lengkap dan kuat. Data sekunder yang digunakan oleh peneliti yaitu berupa rekaman, video, catatan lapangan, dokumen, dan foto. Metode pengumpulan data yang digiunakan oleh peneliti ialah observasi, wawancara dan dokumentasi. Sedangkan instrument yang digunakan ialah pedoman observasi, pedoman wawancara dan dokumentasi. Penulis membuat pedoman wawancara agar pada saat proses wawancara peneliti tidak lagi bingung dengan pertanyaan-pertanyaan yang ingin ditanyakan kepada informan. Selain itu juga bertujuan agar peneliti dapat memperoleh informasi untuk mencapai tujuan penelitian yang diinginkan. Peneliti juga membuat pedoman observasi agar peneliti dapat memperoleh data yang lebih akurat dan menyesuaikan data yang telah diperoleh dari hasil wawancara. Tekhnik pengolahan data yang digunakan ialah reduksi data, penyajian data dan penarikan kesimpulan. Sedangkan analisis data menggunakan reduksi data, penyajian data atau data display, penyimpulan dan verifikasi. Selain itu, peneliti juga melakukan tekhnik keabsahan data yang

${ }^{13}$ Abdul Majid, Belajar dan Pembelajaran Pendidikan Agama Islam, h. 15-16. h. $23-24$

${ }^{14}$ Djam'an Satori dan Aan Komariah, Metodologi Penelitian Kualitatif, Bandung: Alfabeta, 2011,

${ }^{15}$ Djam'an Satori dan Aan Komariah, Metodologi Penelitian Kualitatif, h. 219. 
menggunakan trianggulasi (waktu, tekhnik dan sumber), member chek dan perpanjangan pengamatan.

\section{HASIL DAN PEMBAHASAN PENELITIAN}

A. Penerapan Pendekatan Behavioral Operant Conditioning pada Pembelajaran PAI di Sma Negeri 3 Gowa

Berdasarkan hasil wawancara penulis dengan informan di SMA Negeri 3 Gowa, bahwa pada pembelajaran PAI telah diterapkan pendekatan behavioral operant conditioning baik berupa penguatan positif maupun negatif yang tertuang pada tahap perencanaan, pelaksanaan dan evaluasi.

Tahap perencanaan adalah tahap awal yang harus dilalui oleh pendidik pada setiap proses pembelajaran. Perencanaan dapat di susun oleh guru yang bersangkutan berdasarkan kebutuhan dalam jangka waktu tertentu sesuai yang diinginkan oleh guru yang bersangkutan. Berdasarkan hasil penelitian yang telah dilakukan oleh penulis, guru PAI yang ada di SMA Negeri 3 Gowa telah melakukan perencanaan baik berupa program tahunan, dan semesteran yang tertuang pada RPP. Berikut gambaran rancangan pembelajaran yang telah dibuat dan disusun oleh guru PAI di SMA Negeri 3 Gowa:

1) Nama sekolah

2) Mata pelajaran

3) Kelas/Semester

4) Materi pokok

5) Alokasi waktu

6) Kompetensi Inti

7) Kompotensi dasar dan indikator

8) Tujuan pembelajaran

9) Materi pelajaran

10) Metode pembelajaran

11) Alat/bahan

12) Sumber Belajar

13) Langkah-langkah pembelajaran

14) Penilaian hasil pembelajaran

15) Tanda tangan kepala sekolah dan guru mata pelajaran

Selanjutnya tahap pelaksanaan. Pada tahap pelaksanaan ini, guru PAI di SMA Negeri 3 Gowa mengikuti rancangan proses pembelajaran yang telah disusun pada RPP. Sebelum guru PAI melanjutkan pelajaran pada materi berikunya, diawal pembelajaran guru PAI memberikan apaersepsi berupa pertanyaan kepada peserta didik tentang materi yang telah dibahas pada pertemuan sebelumnya. Sehingga apabila ada siswa yang menjawab pertanyaan tersebut, dengan benar dan tepat guru memberikan nilai kepada siswa tersebut. Selain itu, pada tahap pelaksanaan guru menentukan komponen yang terpenting dalam proses belajar mengajar yaitu menentukan metode yang akan 
digunakan. Oleh karena itu, seorang guru harus menentukan metode yang tepat sesuai dengan materi yang akan dibawakan sehingga peserta didik dengan mudah memahami dan mengerti dengan materi yang disampaikan oleh guru. Berdasarkan hasil penelitian yang telah ditelusuri oleh penulis, guru PAI di SMA Negeri 3 Gowa menggunakan metode pemberian penguatan positif dan negatif pada saat proses belajar mengajar berlangsung. Penerapan penguatan positif berupa pujian, penghargaan, perhatian, hadiah dan pengujian kepada siswa telah diterapkan oleh guru PAI yang ada di SMA Negeri 3 Gowa. Guru memberikan pujian dan penghargaan kepada siswaa yang berprestasi (aktif di dalam kelas) ataupun siswa yang telah menyelesaikan tantangan/tugas dari guru. Guru memberikan penghargaan berupa nilai yang telah dijanjikan oleh guru apabila telah menyelesaikan tugas yang diberikan. Guru menerapkan metode tutor sebaya di dalam pembelajaran PAI. Apabila peserta didik yang diberikan amanah berhasil mengajar teman kelasnya maka peserta didik tersebut akan diberikan nilai yang bagus dari guru yang bersangkutan. Berikut hasil wawancara penulis dengan informan A:

"Penghargaan yang saya berikan ada yang berupa materi dan bukan materi.

Penghargaan yang bukan materi contohnya saya bilang kepada anak-anak ajari temanmu, saya berikan kamu nilai segini. Kalau kau sudah ajar temanmu saya kasikko nilai segini". ${ }^{16}$

Berdasarkan hasil wawancara di atas, maka dapat disimpulkan bahwa guru menggunakan metode tutor sebaya dalam proses belajar mengajar dan memberikan penghargaan berupa nilai kepada siswa yang diberikan tantangan dan amanah dari guru bersangkutan.

Penguatan positif berupa hadiah pun telah diterapkan oleh guru PAI di SMA Negeri 3 Gowa. Guru memberikan hadiah berupa materi kepada siswa yng berprestasi dan kurang mampu. Bentuk-bentuk hadiah tersebut berupa Al-Qur'an, buku dan kerudung. Guru memberikan hadiah tersebut pada akhir semester. Pada semester awal, guru telah memberitahukan kepada siswa-siswi bahwa akan diberikan hadiah pada akhir semester nanti bagi siswa yang berprestasi. Hal ini bertujuan agar siswa-siswi semangat dan lebih giat untuk belajar. Berikut hasil wawancara penulis dengan informan:

$>$ Hasil wawancara informan A

"Saya beri hadiah berupa buku, kerudung bagi siswa yang rengking yang saya lihat siswanya miskin, yang terdiri dari beberapa orang yang menonjol kemampuannya". ${ }^{17}$

$>$ Hasil wawancara informan B

"Saya berikan Al-Qur'an bagi siswa yang berprestasi yang bagus cara membaca Al-

\footnotetext{
${ }^{16}$ Informan A, Guru Pendidikan Agama dan Budi Pekerti. “wawancara” (Bontonompo; 22 Agustus 2017).

${ }^{17}$ Informan A, Guru Pendidikan Agama dan Budi Pekerti. “wawancara” (Bontonompo; 22 Agustus 2017).
} 
Qur'annya yang lancar dan yang terbaik di dalam kelas". ${ }^{18}$

Berdasarkan hasil wawancara di atas, maka dapat disimpulkan bahwa penguatan positif berupa hadiah pun telah diterapkan pada mata pelajaran pendidikan Agama dan budi pekerti di SMA Negeri 3 Gowa.

Selain penguatan positif, guru PAI juga memberikan penguatan negatif berupa teguran, amaran/omelan, teriakan, pukulan kepada siswa telah diterapkan oleh guru PAI yang ada di SMA Negeri 3 Gowa. Akan tetapi penerapan penguatan negatif berupa hukuman tidak diterapkan oleh guru PAI di SMA Negeri 3 Gowa.

Penerapan penguatan negatif berupa teguran, omelan, teriakan dan pukulan diberikan kepada siswa yang nakal atau bersifat kurang ajar. Guru memberikan teguran, teriakan dan amarah/omelan kepada siswa yang memiliki sikap dan perilaku kurang baik yang diperlihatkan pada proses belajar mengajar. Teguran guru diberikan pada proses belajar mengajar yang berlangsung di dalam kelas. Selain itu, guru juga memberikan teguran pada saat guru tersebut bertemu dengan siswa di lingkungan sekolah. Pada saat proses belajar mengajar berlangsung, guru tidak memberikan amarah/omelan dan teguran yang terlalu lama (mendalam). Akan tetapi, guru memberikan teguran dan penjelasanpenjelasan secara mendalam kepada siswa yang bersangkutan ketika bertemu di lingkungan sekolah. Hal ini bertujuan agar siswa yang nakal tersebut tidak terlalu merasa malu kepada siswa yang lain apabila ditegur oleh guru. Penguatan negatif berupa pukulan juga tidak diterapkan pada proses belajar mengajar berlangsung dikelas. Akan tetapi diterapkan diluar proses belajar terkhusus ketika guru dan siswa bersangkutan bertemu di lingkungan sekolah. Guru pukulan kepada siswa yang nakal pada saat guru tersebut bertemu di lingkungan sekolah. Akan tetapi, pukulan yang diberikan tidak akan membuat siswa cacat fisik. Berikut hasil wawancara penulis dengan informan A:

"Saya berikan pukulan atau cubitan kepada siswa yang nakal, akan tetapi pukulan atau cubitan itu tidak merusak badan siswa. Dan selama saya memberikan pukulan kepada siswa, tidak pernah ada siswa yang melapor tentang pukulan atau cubitan yang saya berikan". ${ }^{19}$

Hasil wawancara Penulis dengan informan di atas, dapat dijelaskan bahwa di SMA Negeri 3 Gowa khususnya pada mata pelajaran pendidikan Agama dan budi pekerti diterapkan teguran, pukulan dan omelan kepada siswa terkhusus kepada siswa yang kelakuannya kurang baik. Akan tetapi pukulan yang diberikan guru tidak membuat fisik siswa cacat. Hal ini hanya sebagai teguran bagi siswa yang bersangkutan agar supaya tidak mengulangi perbuatannya yang kurang baik.

\footnotetext{
${ }^{18}$ Informan B, Guru Pendidikan Agama dan Budi Pekerti. “wawancara” (Bontonompo; 22 Agustus 2017).

${ }^{19}$ Informan A, Guru Pendidikan Agama dan Budi Pekerti. “wawancara” (Bontonompo; 22 Agustus 2017).
} 
Selain tahap perencanaan dan pelaksanaan, adapula tahap evaluasi. Pada tahap evaluasi, guru memberikan evaluasi kepada siswa baik pada saat dimulainya pembelajaran, maupun diakhir pembelajaran dalam bentuk tulisan maupun lisan. Diawal pembelajaran guru PAI memberikan evaluasi agar siswa mengingat dan mengetahui materi yang telah diberikan pada pertemuan sebelumnya. Sedangkan pada akhir pembelajaran, guru PAI memberikan evaluasi berupa pertanyaan-pertanyaan kepada siswa. Hal ini bertujuan untuk mengetahui sejauhmana pengetahuan dan pemahaman siswa tentang materi yang telah diberikan pada saat itu. Selain itu, guru PAI juga melakukan penilain berupa penilaian sikap, cara membaca Al-Qur'an dan penilaian pada saat siswa berdiskusi dengan teman kelompoknya atau biasa disebut penilaian diskusi.

\section{B. Faktor Pendukung Dan Penghambat Penerapan Pendekatan Behavioral Operant Conditioning Pada Pembelajaran Pai Di Sma Negeri 3 Gowa}

Faktor pendukung penerapan behavioral operant conditioning pada pembelajaran PAI salah satunya ialah minat belajar siswa. Guru menerapkan metode tutor sebaya di dalam pembelajaran PAI. Apabila peserta didik yang diberikan amanah berhasil mengajar teman kelasnya maka peserta didik tersebut akan diberikan nilai yang bagus dari guru yang bersangkutan. Sehingga, hal ini dapat dikategorikan sebagai faktor pendukung dari penerapan pendekatan behavioral operant conditioning pada pembelajaran PAI. Selain minat belajar siswa, faktor pendukung lain ialah ketersediaan media belajar seperti media gambar yang telah dibuat oleh guru PAI, ketersediaan Al-Qur'an dan buku paket dari sekolah. Berikut hasil wawancara penulis dengan informan B:

"Menggunakan media-media gambar yang kita buat yang dibawa ke sekolah, Al-Qur'an, buku-buku paket". ${ }^{20}$

Berdasarkan hasil wawancara di atas, maka dapat disimpulkan bahwa faktor pendukung penerapan pendekatan behavioral operant conditioning pada pembelajaran PAI ialah ketersediaan media seperti media gambar, buku paket dan Al-Qur'an.

Selain itu, faktor pendukung lain yaitu terlaksananya peraturan-peraturan yang ada di SMA Negeri 3 Gowa yang didukung oleh kerjasama antar guru di SMA Negeri 3 Gowa. Contoh peraturan yang sudah dilaksanakan yaitu peraturan kedisiplinan kedatangan siswa ke sekolah. Sehingga apabila ada siswa yang terlambat datang, maka ia akan diberi hukuman oleh guru, contohnya berdiri di depan sekolah sampai jam pelajaran pertama selesai. Selain itu, siswa juga diberi hukuman agar memungut sampah atau membersihkan lingkungan sekolah.

Selain faktor pendukung, ada pula faktor penghambat dalam pelaksanaan pendekatan behavioral operant conditioning pada pembelajaran PAI yaitu kurangnya minat belajar siswa, siswa kurang lancar membaca ayat suci Al-Qur'an, adanya pengaruh sosial media, kurangnya ketersediaan media seperti media flesdish dan hubungan guru

\footnotetext{
${ }^{20}$ Informan B, Guru Pendidikan Agama dan Budi Pekerti. “wawancara” (Bontonompo; 28 Maret 2018).
} 
dengan orang tua sangat kurang. Sehingga hal inilah yang menjadi faktor penghambat dalam pelaksanaan pendekatan behavioral operant conditioning pada pembelajaran PAI. Berikut hasil wawancara penulis dengan informan B:

"Kurangnya minat belajar siswa itu bukan hanya pada pelajaran agama tetapi kurang minatnya belajar siswa itu secara umum atau pada mata pelajaran lain juga minat belajar siswa kurang, selain itu ada beberapa anak yang kurang lancar membaca Al-Qur'an, banyaknya pengaruh-pengaruh media sosmed, ketersediaan media juga kurang seperti fleshdisk dan kurangnya hubungan orang tua siswa dengan guru. Itu juga biasa orang tuanya tidak mendukung". ${ }^{21}$

Berdasarkan pernyataan di atas, maka dapat disimpulkan bahwa ada beberapa faktor penghambat dari pelaksanaan penerapan pendekatan behavioral operant conditioning pada pembelajaran PAI seperti kurangnya minat belajar siswa, ada siswa yang belum lancar membaca ayat suci Al-Qu'an, pengaruh sosial media, dan pengaruh lingkungan sekitar.

\section{Hasil Penerapan Pendekatan Behavioral Operant Conditioning Pada Pembelajaran Pai Di Sma Negeri 3 Gowa}

Berdasarkan penelitian yang telah dilakukan oleh penulis, maka dapat disimpulkan bahwa penerapan pendekatan behavioral operant conditioning pada pembelajaran PAI di SMA Negeri 3 Gowa sudah terlaksana dengan baik karena guru PAI telah membuat perencanaan pembelajaran RPP, melaksanakan pembelajaran sesuai RPP dan melakukan evaluasi kepada siswa pada setiap sub-sub pokok materi yang tidak terlepas dari pemberian penguatan positif dan negatif, meskipun terkadang pada pelaksnaan pembelajaran kurang sesuai dengan RPP yang telah dibuat oleh guru PAI. Berikut hasil wawancara penulis dengan informan B:

"Kira-kira $80 \%$ pelaksanaan pembelajaran di kelas sesuai rancangan proses pembelajaran selebihnya kurang terlaksana karena adanya faktor penghambat". 22

Berdasarkan hasil wawancara di atas, maka dapat disimpulkan bahwa penerapan pendekatan behavioral operant conditioning secara garis besarnya sudah terlaksana sesuai dengan RPP yang telah dibuat oleh guru PAI di SMA Negeri 3 Gowa.

Selain itu, setelah menerapkan pendekatan behavioral operant conditioning pada pembelajaran PAI di SMA Negeri 3 Gowa guru juga memperoleh kelebihan dan kekurangan pendekatan behavioral operant conditioning baik pada pemberian penguatan positif maupun negatif. Kelebihan yang diperoleh dengan memberikan penguatan positif

${ }^{21}$ Informan B, Guru Pendidikan Agama dan Budi Pekerti. “wawancara” (Bontonompo; 28 Maret 2018). 2018).

${ }^{22}$ Informan B, Guru Pendidikan Agama dan Budi Pekerti. “wawancara” (Bontonompo; 28 Maret 
berupa hadiah membuat siswa semakin bersemangat dalam mengikuti pelajaran pendidikan Agama dan budi pekerti. Siswa bersemangat dan berusaha agar bisa memperoleh nilai yang bagus karena guru yang bersangkutan akan memberikan hadiah berupa buku, kerudung atau Al-Qur'an bagi siswa yang berprestasi. Sehingga penguatan positif berupa hadiah sangat bagus karena membuat minat belajar siswa tinggi. Berikut hasil wawancara Penulis dengan informan B:

"Kelebihan yang diperoleh dengan memberikan hadiah ialah siswa-siswi berlomba dan terdorong untuk lebih giat belajar". ${ }^{23}$

Berdasarkan hasil wawancara di atas dapat disimpulkan bahwa dengan memberikan hadiah kepada siswa akan membuat siswa yang bersangkutan lebih giat belajar.

Begitu pula dengan pemberian penghargaan berupa nilai yang telah dijanjikan oleh guru kepada siswa. Siswa yang diberi tantangan oleh guru semakin semangat dan tertantang terhadap tugas yang diberikan. Sehingga siswa yang bersangkutan sangat aktif dan semangat dalam menyelesaikan tugas yang diberikan. Selain itu, dengan memberikan pujian bagi siswa yang berprestasi, membuat siswa lain termotivasi agar dapat menjadi seperti siswa yang berprestasi tersebut. Hal tersebut sesuai dengan kelebihan teori Skinner yaitu dengan adanya penguatan, menjadikan motivasi bagi individu untuk berperilaku yang benar sesuai dengan keinginan.

Selain kelebihan yang diperoleh dengan pemberian penguatan positif, ada pula kelebihan yang diperoleh dengan memberikan penguatan negatif. Penguatan negatif berupa teguran, marah, teriakan dan pukulan juga menghasilkan kelebihan yaitu dengan memberikan penguatan negatif kepada siswa yang kurang baik perilakunya, membuat siswa yang bersangkutan menjadi jerah dan perilakunya berubah menjadi baik. Akan tetapi, hal ini bersifat individual yaitu tergantung dengan siswa yang bersangkutan. Hal ini sesuai dengan pernyataan informan $\mathrm{A}$ :

"Mengenai kelebihan yang diperoleh tergantung dengan siswa yang bersangkutan. Ada siswa apabila diberi teguran perilakunya semakin memburuk akan tetapi ada juga siswa memperhatikan dan merubah perilakunya. Jadi, tergantung dengan siswa dan karakter masing-masing. Ada yang bertambah nakal, ada yang berubah lebih baik. Tergantung dengan karakter anak-anak. Karena anak-anak bermacam-macam karakternya". ${ }^{24}$

Berdasarkan pernyataan di atas, maka dapat di simpulkan bahwa dengan memberikan penguatan negatif membuat perilaku siswa lebih baik daripada perilaku sebelumnya.

\footnotetext{
${ }^{23}$ Informan B, Guru Pendidikan Agama dan Budi Pekerti. “wawancara” (Bontonompo; 22 Agustus 2017).

${ }^{24}$ Informan A, Guru Pendidikan Agama dan Budi Pekerti. “wawancara” (Bontonompo; 22 Agustus 2017).
} 
Selain kelebihan adapula kekurangan penerapan pendekatan Behavioral Operant Conditioning ialah dengan memberikan penguatan positif berupa hadiah kepada siswa yang berprestasi membuat siswa yang lainnya merasa iri kepada siswa yang diberikan hadiah tersebut. Selain itu, ada pula kekurangan yang lainnya yaitu dengan memberikan penguatan negatif berupa teguran bagi siswa yang kurang baik perilakunya membuat siswa yang bersangkutan semakin membangkan kepada guru. Sehingga siswa yang berperilaku buruk, semakin bertambah perilaku buruknya. Sehingga persoalan tersebut membutuhkan cara tersendiri agar dapat terselesaikan. Hal ini sesuai dengan hasil wawancara Penulis dengan informan A:

“Ada siswa apabila diberi teguran perilakunya semakin memburuk akan tetapi ada juga siswa memperhatikan dan merubah perilakunya. Jadi, tergantung dengan siswa dan karakter masing-masing. Ada yang bertambah nakal, ada yang berubah lebih baik. Tergantung dengan karakter anak-anak. Karena anak-anak bermacam-macam karakternya". ${ }^{25}$

Berdasarkan hasil wawancara tersebut maka dapat disimpulkan bahwa dengan memberikan penguatan negatif maka akan membuat perilaku siswa semakin memburuk atau membangkan.

\section{KESIMPULAN}

Berdasarkan penelitian yang telah dilakukan mengenai penerapan pendekatan behavioral operant conditioning pada pembelajaran PAI di SMA Negeri 3 Gowa, maka penulis dapat menyimpulkan bahwa:

1. Penerapan pendekatan behavioral operant conditioning pada pembelajaran PAI di SMA Negeri 3 Gowa khusunya pemberian penguatan positif dan negatif sudah terlaksana dengan baik karena guru PAI telah melakukan perencanaan yang tertuang di dalam RPP, melaksanakan proses belajar mengajar sesuai yang tercantum di dalam RPP dan melakukan evaluasi pembelajaran. Meskipun pemberian penguatan positif dan negatif tidak tercantum langsung di dalam perencanaan pembelajaran RPP, akan tetapi pada pelaksanaannya di dalam kelas terdapat pemberian penguatan positif dan negatif.

2. Faktor pendukung dan penghambat penerapan pendekatan behavioral operant conditioning pada pembelajaran PAI

Faktor pendukung penerapan pendekatan behavioral operant conditioning pada pembelajaran PAI yaitu minat belajar siswa, ketersediaan media belajar baik berupa media gambar, buku cetak dan Al-Qur'an. Selain itu, faktor pendukung lain yaitu terlaksananya peraturan-peraturan yang ada di SMA Negeri 3 Gowa yang didukung oleh kerjasama antar guru di SMA Negeri 3 Gowa.

\footnotetext{
${ }^{25}$ Informan A, Guru Pendidikan Agama dan Budi Pekerti. “wawancara”(Bontonompo; 22 Agustus 2017).
} 
Sedangkan faktor yang menghambat pelaksanaan penerapan pendekatan behavioral operant conditioning pada pembelajaran PAI yaitu kurangnya minat belajar siswa, siswa kurang lancar membaca ayat suci Al-Qur'an, adanya pengaruh sosial media, kurangnya ketersediaan media seperti media flesdish dan hubungan guru dengan orang tua sangat kurang.

Hasil dari penerapan pendekatan behavioral operant conditioning pada pembelajaran PAI di SMA Negeri 3 Gowa. Berdasarkan penelitian yang telah dilakukan oleh penulis, maka penulis dapat menyimpulkan bahwa penerapan pendekatan behavioral operant conditioning pada pembelajaran PAI sudah berjalan dengan baik karena dalam pelaksanaan proses belajar mengajar $80 \%$ sudah sesuai dengan apa yang telah direncanakan oleh guru PAI yang telah tertuang di dalam RPP. Meskipun pada dasarnya dalam perencanaan pembelajaran /RPP pemberian penguatan positif dan negatif tidak tertulis, akan tetapi dalam pelaksanaannya di dalam kelas guru memberikan penguatan positif dan negatif kepada siswa sehingga siswa semakin bersemangat dalam mengikuti proses belajar mengajar di dalam kelas karena guru memberikan penguatan positif kepada siswa.

\section{DAFTAR PUTAKA}

Anwar, Chairil. Teori-Teori Pendidikan: Klasik Hingga Kontemporer. Cet. 1; Yogyakarta: IRCiSoD 2017.

Jalaluddin dan Abdullah Idi. Filsafat Pendidikan: Manusia, Filsafat dan Pendidikan. Cet. 3; Jakarta: PT Rajagrafindo Persada, 2013.

Khodijah, Nyayu. Psikologi Pendidikan. Cet. 3; Jakarta: PT RajaGrafindo Persada, 2016.

Latuconsina, Nurkhalisah. Pengelolaan dalam Kelas Pembelajaran. Cet. 1; Makassar: Alauddin University Press, 2013.

Majid, Abdul. Belajar dan Pembelajaran Pendidikan Agama Islam. Cet. 1; Bandung: PT Remaja Rosdakarya, 2014.

Suhardan, Dadang, dkk. Manajemen Pendidikan. Cet. 3; Bandung: Alfabeta, 2014.

Satori, Djam'an dan Aan Komariah. Metodologi Penelitian Kualitatif. Cet. 3 ; Bandung : Alfabeta, 2011.

Taher, Thahroni. Psikologi Pembelajaran Pendidikan Agama Islam. Cet. 1; PT RajaGrafindo Persada: Jakarta, 2013.

W. Santrock, John. Psikologi Pendidikan. Cet. 6; Jakarta: Prenadamedia Group, 2015. 